УДК 378.011.3-051.316.77

DOI: 10.31339/2617-0833-2018-2(25)-121-124

ПРОФЕСІЙНО-МОВЛЕННСВА КУЛЬТУРА В ПЕДАГОГІЧНІЙ ДІЯЛЬНОСТІ МАЙБУТНЬОГО ВЧИТЕЛЯ

Курило О.Й., Прокопович Л.С.

\title{
OFESSIONAL-SPEECH CULTURE IN THE PEDAGOGICAL ACTIVITY OF A FUTURE TEACHER
}

Kurylo Oleksandra, Prokopovich Lidiya

У статті розглядаються питання щэодо формування культури професійного мовлення як одного з найважливіших складників педагогічної культури вчителя; виокремлено структурні особливості та розкрито комунікативні якості професійного мовлення педагога. Визначено теоретичну та практичну основи культури мовлення. Розглянуто найбільш оптимальні шляхи вдосконалення мовленнєвої культури майбутнього педагога.

Ключові слова: мовлення, мовленнєва культура, мовленнєва компетентність, комунікативні якості, шляхи вдосконалення мовлення.

The article deals with the formation of a culture of professional speech as one of the most important components of teacher's pedagogical culture; the structural features of the teacher's speech, in particular its duration, horizontal and vertical division, the usage of tropes and rhetorical figures are singled out. The definition of the concepts "speech culture", "speech competence" and others are given. The communicative qualities of professional speech of a teacher are revealed, namely: correctness, content, relevance, sufficiency, logic, accuracy, clarity, conciseness, simplicity and emotional expressiveness, imagery, colorfulness, purity and emotionality. The theoretical basis of speech culture of a future teacher which includes knowledge of orthoepic, accentuation, lexical, grammatical and morphological norms is determined and practical basis of speech culture is outlined. The most optimal and effective ways of improving speech culture of the future teacher are reviewed.

Key words: speech, speech culture, speech competence, communicative qualities, ways of improving speech.

Культура мовлення є одним із головних показників розвитку суспільства. Це пояснюється тим, що процес опанування мовою та мовною культурою пов'язаний із здобуттям та розвитком навичок правильно розмовляти й писати, вмінням точно формулювати та висловлювати свої думки, активно використовувати мовні знання у спілкуванні. Досконале володіння культурою мовлення є важливим компонентом підготовки педагогічних фахівців, оскільки саме творче використання засобів повною мірою виявляє професійні обдарування вчителя, сприяє його самотворенню та самовираженню.

Актуальність теми дослідження полягає в тому, що мовленнєва культура майбутнього педагога $є$ одним із основних складників його професійної діяльності. Вона грунтується на знаннях теоретичних основ, норм сучасної української літературної мови, що сприяє формуванню мовленнєвих умінь і навичок. Мовленнєва компетентність вчителя - це один із найважливіших елементів його загальної та професійної культури, який відтворює ціннісні орієнтації, характеризує його вихованість, уміння висловлювати думки, дотримуватись етичних норм спілкування тощо. Досконале володіння мовою, опанування вчителем культури мовлення, мовленнєвого етикету $\epsilon$ передумовою ефективності професійної та особистісної комунікації.

Проблемам спілкування майбутнього вчителя присвяченого чимало праць, в яких розглядається ряд найважливіших питань, зокрема: теоретично-методологічні основи професійного спілкування (В. Киричук, С. Максименко, Л. Савенкова, Т. Яценко та ін.); 
формування індивідуального стилю педагогічного спілкування (А. Андрєєв, В. Галузяк, Г. Мешко тощо); формування комунікативних умінь і навичок (З. Білоусова, В. Каплинський, С. Коваль, В. Москалець та ін.); способи комунікативної підготовки (О. Березюк, В. Наумов тощо); культура педагогічного спілкування (Ф. Байкін, Т. Гриценко, С. Омельченко та ін.); формування комунікативних якостей мовлення (А. Богуш, О. Бєляк, О. Заболотська, В. Пасинок тощо); формування комунікативної компетентності (О. Бєляєв, М. Вашуленко, I. Зимняя, А. Капська, Л. Мацько, М. Пентилюк, В. Півторацька, Л. Савенкова, Г. Сагач та ін.).

Так, зокрема вивченню комунікативної культури присвячені праці С. Абрамович, В. Бондар, О. Грейліх, І. Комарова, Н. Путільовської та ін. Як зазначає І. Комарова, основою комунікативної культури є якісна інформаційно-смислова сторона педагогічної взаємодії та здатність учителя чітко, зрозуміло й переконливо висловлювати свої думки та почуття за допомогою вербальних і невербальних засобів інформаційного обміну з учнями [6, с.9]. На думку О. Грейліх, комунікативна культура має таку структуру: когнітивну, операційну, практично-дійову компетентності. Мовленнєва культура педагога містить психічні властивості та особливості мислення (відкритість, гнучкість, нестандартність асоціативного ряду, розвиненість внутрішнього плану дій тощо). А найважливішим компонентом комунікативної культури $є$ вільне володіння мовою (наявність великого запасу слів, образність, точне сприйняття усного слова й точну передачу ідей співрозмовника своїми словами) [5]. Н. Путіловська вважає, що основою фахової мовленнєвої культури є система комунікативних умінь, які не існують без мовленнєвої діяльності, що тільки в ній вони проявляються і формуються. Крім того, дослідниця вказує на те, що комунікативні вміння $\epsilon$ основою формування фахової мовленнєвої культури майбутнього вчителя [7]. Комунікативна культура $€$ складовою (компонентом) професійної та педагогічної культури педагога, тому ототожнюємо мовленнєву культуру з професійним педагогічним спілкуванням [3, с. 307].

Метою статті є розкриття педагогічної ефективності мовлення майбутнього вчителя, яка залежить від рівня володіння мовою, правильного добору мовних засобів, тобто від культури мови.

Як відомо, мовлення є складовою педагогічної майстерності вчителя, інструментом його професійної діяльності, за допомогою якого можна вирішити різні педагогічні завдання. Мовлення вчителя - це й показник його педагогічної культури, засіб самовираження та самоутвердження особистості, певний зразок комунікативної дії, яку школярі усвідомлено чи неусвідомлено копіюють. Саме тому сформованість культури мовлення $\epsilon$ важливим показником професіоналізму майбутнього педагога.

Культура мовлення - це впорядкована сукупність нормативних, мовленнєвих засобів, вироблених практикою людського спілкування, які оптимально виражають зміст мовлення i задовольняють умови й мету спілкування. Важливими характеристиками культури мовлення є правильність,змістовність, доречність, достатність, логічність, точність, ясність, стислість, простота та емоційна виразність, образність, барвистість, чистота, емоційність. Правильна вимова, вільне, невимушене оперування словом, уникнення вульгаризмів, провінціалізмів, архаїзмів, слів-паразитів, зайвих іншомовних слів, наголошування на головних думках, фонетична виразність, інтонаційна розмаїтість, чітка дикція, розмірений темп мовлення, правильне використання логічних наголосів та психологічних пауз, взаємовідповідність між змістом і тоном, між словами, жестами та мімікою - необхідні елементи мовної культури вчителя [4, с. 127].

Теоретичною основою культури мовлення майбутнього педагога $є$ пізнання й осмислення літературних норм: орфоепічних, які регламентують правила вимови звуків, звукосполук та граматичних форм слів; акцентуаційних, що визначають правильне наголошування слів; лексичних, які регламентують слововживання; граматичних, що стосуються вживання граматичних форм слів, побудови словосполучень, речень; морфологічних, які передбачають вживання в мовленні повнозначних змінних слів, граматична оформленість яких відповідає нормі української літературної мови. 
Авраменко В., у свою чергу, подає своє трактування теоретичної та практичної основ культури мовлення. Так, на їі думку, теоретичною основою мовленнєвої культури $€$ пізнання й осмислення мовних норм, особливостей функціонування стилів літературної мови, усвідомлення взаємозв'язків системи мови, структури мовлення й екстралінгвістичних структур; практичною - систематична увага мовця до мови й рівня власного мовлення, прагнення досягти мовленнєвої майстерності [1, с. 124].

Розрізняють такі структурні особливості мовлення вчителя: а) тривалість мовлення. Вона залежить від його жанрової належності (урок, бесіда, доповідь, повідомлення, лекція, мітингова промова та ін.) і визначається тим, хто говорить, на основі комунікативної інтенції (спрямованості), теми та ситуації спілкування; б) горизонтальне членування — розміщення всіх частин виступу, змісту занять, організація матеріалу за певною системою, що створює відчуття логічної стрункості й динамічності мовлення, допомагає спрямовувати думку аудиторії в потрібне русло; в) вертикальне членування — підпорядкованість частин тексту за значущістю. Йдеться про те, що окремі підтеми головної частини включають певну кількість смислових сегментів, які 3 різною ефективністю доносять інформацію до адресата; г) використання тропів - вживання слів і висловів у переносному значенні, коли у свідомості промовця і слухачів їх пряме й переносне значення є найважливішим засобом створення виразності мовлення під час публічного виступу (використання оратором метафор, порівнянь, метонімії, іронії, парадоксу та ін.); г) використання риторичних фігур. Це підсилює виразність, експресивність мовлення, силу його впливу на адресата, чому сприяє і вживання особливих синтаксичних конструкцій: антитези, градації, повтору, анафори, епіфори, паралелізму, риторичного звертання та ін.[1, с. 123].

Існує безліч шляхів до вдосконалення мовленнєвої культури й формування мовної особистості майбутнього вчителя, як засвідчує практика та результати наукових досліджень. Проте всі вони починаються з прояву любові до рідної мови, бажання вивчати іï, майстерно нею володіти. Серед ряду дієвих та оптимальних шляхів удосконалення мовленнєвої культури майбутнього педагога можна визначити такі:

1. Вивчати мову й читати тексти вголос із дотриманням нормативних вимог.

2. Користуватися словниками, довідниками та посібниками.

3. Вивчати твори художньої літератури напам'ять, збагачуючи словниковий запас i черпаючи багатство з народної творчості.

4. Не говорити швидко, дотримуватися пауз і мелодики мовлення.

5. Вивчати мовлення майстрів слова .

6. Виробляти в собі навички мовленнєвого самоконтролю та самоаналізу.

7. Намагатися систематично записувати власні думки й цікаві спостереження, робити перекази з однієї мови на іншу з метою уникання помилок ( суржику, кальки).

8. Оволодівати різними стилями мовлення ( як усного, так і писемного) [8, с. 80].

Як бачимо, культура мовлення майбутнього педагога набуває в сучасному світі особливої ваги й потребує постійного самовдосконалення. Вона $є$ не лише показником професійних якостей вчителя, а й фактором, що впливає на його визнання серед педагогів. Учителі, які не володіють мовленням на належному рівні, не можуть бути задоволеними собою, що негативно позначається на їхній поведінці, професійній діяльності, навіть приватному житті [2, с. 260].

Отже, майбутній педагог повинен бути всебічно розвиненою й високоосвіченою особистістю, а тому вдосконалення культури мовлення є невід'ємною частиною формування його професійних якостей, органічною потребою національного виховання фахівців освітньої галузі та суспільства загалом. У результаті дослідження з'ясовано: проблема мовленнєвої культури майбутніх учителів $є$ складною, багатоаспектною й такою, що не отримала остаточного й повного вирішення. Перспективи дослідження вбачаємо в більш глибокому й детальному вивченні кожного 3 компонентів культури мовлення, які сприятимуть оптимізації процесу розвитку мовленнєвої культури майбутніх педагогів. 


\section{Список використаних джерел}

1. Авраменко В. Культура мовлення учителя як засіб професійно-педагогічної комунікації / В.Авраменко //Проблеми підготовки сучасного вчителя. - 2010. - №1. - С.120125.

2.Бутенко Н.Ю. Комунікативна майстерність викладача: Навч. посібник / Н.Ю.Бутенко. - К.: КНЕУ, 2005. - 336 с.

3 Варга Л.І. Визначення сутності поняття "комунікативна культура" в науковій літературі / Л.І. Варга // Збірник наукових праць [ Херсонського державного університету]. Педагогічні науки. - 2015. - Вип.67. - С.307-311.

4. Волкова Н.П. Професійно-педагогічна комунікація: Навч. посіб / Н.П. Волкова. К.:ВЦ «Академія», 2006. - 256 с.

5. Грейліх О. Комунікативна культура як компонент педагогічної культури викладача вищого навчального закладу [Електронний ресурс]. - Режим доступу до документу: http:// irbis-nbuv.gov.ua/.../cgiirbis_64.exe.

6. Комарова I.I. Формування у майбутніх учителів культури педагогічного спілкування:Автореф. дис. канд. пед. наук: 13.00.04 / І.І. Комарова. - Тернопіль, 2000. - 19с.

7. Путіловська Н.Б. Місце комунікативної культури в професійно-педагогічній підготовці майбутнього вчителя [Електронний ресурс]. - Режим доступу до документу: http:// irbis-nbuv.gov.ua/.../cgiirbis_64.exe.

8. Штома Л.Н. Мовленнєва культура вчителя як компонент педагогічної майстерності / Л.Н.Штома //Інформаційно-комунікаційні технології в сучасній освіті: досвід, проблеми, перспективи: зб. Матеріалів III Міжнародної науково-практичної конференції . 12-14 листопада 2012 р. - С.78-81.

\section{References}

1. Avramenko V.(2010), Teacher's speech culture as a means of vocational and pedagogical communication [«Kultura movlennya uchytelya yak zasib profesiyno-pedahohichnoyi komunikatsiyi»], Problemy pidhotovky suchasnoho vchytelya, №1, Uman, pp.120-125.

2. Butenko N.YU.(2005), Komunikatyvna maysternist' vykladacha: Navch. posibnyk [Communicative teacher skills: Teaching manual], KNEU, Kiev, 336p.

3. Varha L.I.(2015), Definition of the essence of the concept "communicative culture" in scientific literature [«Vyznachennya sutnosti ponyattya "komunikatyvna kul'tura" v naukoviy literaturi »], Zbirnyk naukovykh prats [ Khersonskoho derzhavnoho universytetu]. Pedahohichni nauky, № 67, Kherson, pp.307-311.

4. Volkova N.P.(2006), Profesiyno-pedahohichna komunikatsiya: Navch. posibnyk [Professional-pedagogical communication: Teaching. manual ], VTS «Akademiya», Kiev, 256 p.

5.Hreylikh O.(2012), Communicative culture as a component of the pedagogical culture of a teacher of a high educational establishment [«Komunikatyvna kultura yak komponent pedahohichnoyi kultury vykladacha vyshchoho navchalnoho zakladu»], Psykholinhvistyka, №9, Available at: http://nbuv.gov.ua/UJRN/psling._[07.09.2012]

6. Komarova I.I.(2000), Formation of culture of pedagogical communication of future teachers: abstract [Formuvannya u maybutnikh uchyteliv kul'tury pedahohichnoho spilkuvannya: avtoref. dis. kand. ped. nauk], Ternopil, 19 p.

7. Putilovs'ka N.B.(2011), The place of communicative culture in the vocational and pedagogical training of a future teacher [«Mistse komunikatyvnoyi kul'tury $\mathrm{v}$ profesiynopedahohichniy pidhotovtsi maybutn'oho vchytelya»], Naukovi pratsi. Pedahohika, №173 (161), Available at: http://nbuv.gov.ua/UJRN/Npchduped.[05.05.2011]

8. Shtoma L.N.(2012), Teacher's speech culture as a component of pedagogical skills [«Movlennyeva kul'tura vchytelya yak komponent pedahohichnoyi maysternosti »], Informatsiynokomunikatsiyni tekhnolohiyi v suchasniy osviti: dosvid, problemy, perspektyvy: zb. Materialiv III Mizhnarodnoyi naukovo-praktychnoyi konferentsiyi, №2 (3), Kiev-Lviv, pp. 78-81. 